\title{
Transatlantica
}

Revue d'études américaines. American Studies Journal

1 | 2013

Revisiting the Gilded Age / Littérature et philosophie

\section{The Economics and Politics of Louisiana's Latest French Renaissance}

Jérôme Degrave

\section{(2) OpenEdition}

1 Journals

Édition électronique

URL : https://journals.openedition.org/transatlantica/6461

DOI : 10.4000/transatlantica.6461

ISSN : $1765-2766$

Éditeur

Association française d'Etudes Américaines (AFEA)

Référence électronique

Jérôme Degrave, "The Economics and Politics of Louisiana's Latest French Renaissance »,

Transatlantica [En ligne], 1 | 2013, mis en ligne le 31 janvier 2014, consulté le 02 février 2023. URL

http://journals.openedition.org/transatlantica/6461 ; DOI : https://doi.org/10.4000/transatlantica. 6461

Ce document a été généré automatiquement le 2 février 2023

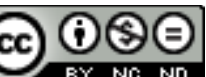

Creative Commons - Attribution - Pas d'Utilisation Commerciale - Pas de Modification 4.0 International - CC BY-NC-ND 4.0

https://creativecommons.org/licenses/by-nc-nd/4.0/ 


\title{
The Economics and Politics of Louisiana's Latest French Renaissance
}

\author{
Jérôme Degrave
}

1 Louisiana French is dying. With fewer than 160,000 speakers and an extremely limited trans-generational transmission, the language of the Cajuns ${ }^{1}$ is fast disappearing although the main facets of their culture - food and music - continue to enjoy international fame. This paradox is not the only one: Louisiana is the only state in the USA which took the trouble to endow itself with a public agency meant to defend and diffuse a minority language, namely French. Created in 1968 by an act of the Louisiana Legislature, CODOFIL (Council for the Development of French in Louisiana) has proven unable to hinder the decline of the language it was supposed to champion ${ }^{2}$, a decline that may be regarded as irreversible.

2 A recent spate of laws voted unanimously by the Louisiana Legislature may yet prove the contrary and underline the extraordinary resilience of a language that has been spoken in Louisiana in various forms since 1699 (the first Acadians, now called Cajuns, settled in 1765). Act 679 , introduced by Senator Eric LaFleur ${ }^{3}$ from Louisiana's $28^{\text {th }}$ district in 2010, tackles some of the most obvious problems affecting French in Louisiana, including the chronic inefficiency of CODOFIL and its lack of accountability. It defines the new mission of CODOFIL as well as its structure. Act 212 completes Act 679 in that it deals specifically with one of the new missions of CODOFIL, namely the expansion of French immersion programs. As for Act 106, adopted one year later in 2011, it seeks to establish a French Language Services Program and thus turn a heritage language into a utilitarian one all over again. Two more laws were voted in 2012 to confirm this new legislative activity around the French language: Act 851, which paves the way for the creation of a world language immersion school at the University of Louisiana at Lafayette, and Act 202 which establishes French as the official language of CODOFIL. 
3 This paper intends to examine this prospective and rather unexpected ${ }^{4}$ French renaissance, its foundations and objectives. As a preamble, the action of CODOFIL in the field of education until 2010 and the ensuing reasons for reforming this unique agency shall be examined. Some of the recent laws voted by the legislature of Louisiana shall then be analyzed as well as the motivations of the legislators sponsoring this French revival so as to determine how the new focus on immersion teaching may affect the status of the French language in the state and be conducive to a resurgence of French speakers while simultaneously profiting the economy. This paper shall finally propose an assessment of the revival in progress as the laws fuelling it betray the legislators' sense of urgency and a dire need for results.

\section{From the "Old" CODOFIL to the "New" CODOFIL}

The founding president of CODOFIL, James Domengeaux, used to claim that "School has destroyed French, schools must rebuild it". Focusing the action of his agency on education, Domengeaux aimed at turning Louisiana schoolchildren into bilingual individuals. This choice set the policy of CODOFIL for the decades to come and inevitably became the benchmark by which the results of CODOFIL must be appraised.

If numbers and statistics are to be trusted, CODOFIL did succeed, for a time, in the field of education. The Foreign Language in the Elementary School program (FLES) numbered around 25, 000 pupils in 1972 and they were twice as many four years later (Smith-Thibodeaux, 1977, 94). Earlene Broussard, the first Cajun to be director of CODOFIL (1992-1997), even declared in 1996 that with 80, 000 pupils enrolled in the FLES program and 650 French Louisiana native speakers teaching them: "Nous avons réussi notre mission originale ${ }^{5 "}$. Behind those flattering figures lay an utterly different picture where schoolchildren repeatedly proved unable to communicate in French with their grand parents and where teachers were either foreigners (and thus unable to teach the Louisiana French vernacular) or grossly under skilled (some Louisianian teachers took advantage of a program called Second Language Specialists created in 1978 and meant to replace foreign French teachers, in which quantity prevailed over quality). As a result, a growing number of schools closed their FLES programs, especially in those parishes retaining a still considerable French-speaking community ${ }^{6}$. Disaffection with the daily 30-minute lessons and the standardized French taught in the classroom account for the decline.

6 The limits and disappointing results of the FLES program were not lost on everybody and the French immersion programs experimented in the late 1970's in Canada proved impressive enough for Domengeaux to accept the opening of one such program in East Baton Rouge in 1981. Pupils were no longer taught French but in French. The results of this first experiment led to a rapid expansion of immersion programs in the South of Louisiana, from Lake Charles to New Orleans. Indeed, studies led in Canada and in Louisiana (Wayne; Boudreaux; Boudreaux and Caldas; Haj-Broussard) but also the mere realization by parents that their children were making tangible headway in French primed the pump: 861 pupils enrolled in French immersion programs in 1993-1994, 3,416 in 2010-2011. Though impressive, this figure cannot compare with the total number of school children, which fluctuates around 700, 000. More worrying than this imbalance is the fact that not a single new immersion program was opened after 2000 while 14 schools got rid of their programs between 1985 and $2009^{8}$. The growing 
number of immersion pupils is simply due to the expansion of existing programs, mainly those of New Orleans and Lafayette. Lafourche, one of the most Cajun parishes in Acadiana ${ }^{9}$, is a good example of CODOFIL's failure to support and expand immersion programs. After a parent support group (Les Amis du français de Lafourche) asked for an immersion program in the parish in 2001, the mostly-Cajun members of the parish school board rejected the demand claiming that "we are not convinced that total immersion produces any meaningful results in mastery of a particular curriculum area. Furthermore, there is no significant or overriding public opinion to have such a program" (James, 2009). Considering the available studies in favor of immersion teaching, such claims should have easily been shattered by CODOFIL had it wished to get involved. This failed attempt at establishing an immersion program was to be the last one of the decade in Acadiana where only seven parishes out of twenty-two could boast an immersion program in 2010-2011.

7 Though grievances against CODOFIL were numerous - many Cajun activists and French Associate Teachers (FATs) derided the agency as a simple provider of visas (Degrave, 265) - it is first and foremost the inability of CODOFIL to increase the number of immersion programs that led the Louisiana Legislature to react:

En 2004, j'ai développé ... nous avons adopté la Commission du Français en Louisiane, pour faire une étude : qu'est ce qui se passait avec la langue française dans la Louisiane ? Pourquoi la langue continuait à mourir ? Est-ce qu'il n'y avait pas assez d'argent, ou peut-être pas assez d'intérêt, peut-être qu'il n'y a pas une bonne organisation pour le promouvoir? Mais c'était le CODOFIL qui était là... Il y a eu une réunion ici à Baton Rouge, avec des professeurs, des étudiants, des parents d'élèves qui avaient leurs enfants dans des programmes d'immersion. Tous disaient la même chose : 'le programme marche très bien, mais nous avons besoin de plus d'écoles d'immersion.' Mais la question, c'était, qui va le faire ? Qui va les créer ? Le Département de l'Éducation? Non. Parce que c'est le rôle du CODOFIL. Mais le CODOFIL n'a rien fait. ${ }^{10}$

8 It then took six years for Senator LaFleur to gather the necessary political clout ${ }^{11}$ to set off the on-going legislative activity meant to reform CODOFIL of which Act 679 is the cornerstone. Unanimously voted by the members of the Legislature in June 2010, this first law clearly proved that they meant business and were not engaged in some kind of last-ditch symbolic effort so that the French language in Louisiana could perish with honors. The act tackles some of the most obvious problems affecting French in Louisiana, including the chronic inefficiency of CODOFIL as far as immersion programs expansion is concerned, its invisibility ${ }^{12}$ and lack of accountability.

Regarding the CODOFIL board as a "political dumping ground for appointees" (Alford) used by the governor of Louisiana to gratify some of his lesser political allies with one of its fifty seats, LaFleur restricted the board to twenty-three members and granted the right to appoint them to associations and entities acknowledged for their involvement in the defense and promotion of Louisiana French. Seven members, including the chairman of CODOFIL, are now chosen by the board to sit on an executive council that will determine its strategy and thus avoid the lack of orientation that defined the policy of CODOFIL over the past decade. So as to prevent such a possibility, the legislators (and more especially those belonging to the Louisiana section of the Assemblée des Parlementaires Francophones - often dubbed the Cajun caucus -, whose president is Senator LaFleur) are obviously resolved to keep an eye on the workings of the Council as they are responsible for the appointment of four members. This long 
overdue structural reform is meant to enable the new CODOFIL to achieve the goals assigned by Act 679 which cover three major fields: education, the economic interest of Louisiana and the relationship with other French-speaking countries.

\begin{tabular}{|c|c|c|c|c|}
\hline & Education & Elected bodies & $\begin{array}{l}\text { Non-profit } \\
\text { associations }\end{array}$ & Institutions \\
\hline & $\begin{array}{l}\text { Louisiana } \\
\text { Consortium of } \\
\text { Immersion Schools } \\
(4) \\
\text { Louisiana Chapter of } \\
\text { the American } \\
\text { Association of } \\
\text { Teachers of French } \\
(2) \\
\text { Consortium of } \\
\text { Louisiana Colleges } \\
\text { and Universities (2) } \\
\text { Louisiana } \\
\text { Educational } \\
\text { Television Authority } \\
\text { (1) }\end{array}$ & $\begin{array}{l}\text { Louisiana Section of } \\
\text { the Assemblée des } \\
\text { Parlementaires } \\
\text { Francophones (4) } \\
\text { Governor (2) } \\
\text { Mayor of New Orleans } \\
\text { (or his designee) (1) }\end{array}$ & $\begin{array}{l}\text { La Fondation } \\
\text { Louisiane (1) } \\
\text { United Houma } \\
\text { Nation (1) } \\
\text { Association } \\
\text { Louisiane Acadie (1) } \\
\text { Francophone } \\
\text { Section of the } \\
\text { Louisiana State Bar } \\
\text { Association (1) }\end{array}$ & $\begin{array}{l}\text { Le Centre } \\
\text { International de } \\
\text { Lafayette (1) } \\
\text { Louisiana Chapter of } \\
\text { the French-American } \\
\text { Chamber } \\
\text { commerce (1) } \\
\text { Louisiana Cultural } \\
\text { Economy Foundation } \\
(1)\end{array}$ \\
\hline $\begin{array}{l}\text { Seat } \\
\text { totals }\end{array}$ & 9 & 7 & 4 & 3 \\
\hline
\end{tabular}

FIgURE 1

Composition of CODOFIL (Number of appointees into brackets)

\section{Legislative Action in Favor of French Immersion: Nature and Reasons}

10 Act 679 does not question CODOFIL's traditional policy which has so far consisted in focusing on education, but clearly identifies the teaching model that must be favored and that which must consequently be rejected. French immersion programs must be promoted and developed while FLES programs are not even mentioned. The objectives CODOFIL will have to reach with regard to immersion programs are the following:

(3) To promote, support, and enhance French language immersion educational programs and instruction at all levels of elementary and secondary education in the state by working cooperatively and collaboratively with the State Board of Elementary and Secondary Education and the State Department of Education.

(4) To develop a model French immersion program which can be used by any school seeking to establish a French immersion program within its curriculum.

(5) To increase the number of French immersion schools in the state, with the specific goal of establishing, not later than September 1, 2015, at least one French immersion school in East Baton Rouge Parish and in each of the (...) parishes which comprise the Acadiana Region. (Act 679, art. 659, para. C) 
11 Act 679 may herald a drastic change in the teaching of French in Louisiana as the immersion programs are now considered the pillar of the state's new linguistic policy. Yet, the failure of CODOFIL to support and extend them throughout Acadiana has weakened and undermined the immersion programs and left them vulnerable. Unchallenged by CODOFIL, some school principals are reluctant to acknowledge that immersion students need different working conditions and adjustments on the grounds that they make up a minority within the school. This uncompromising attitude makes life harder for some pupils whose academic achievements often decrease, which leads to their dropping out of the program. Since a pupil in an immersion class cannot be easily replaced - it is nearly impossible to find pupils fluent enough in French to start immersion from scratch after first grade - some programs suffer from depletion and have to be closed or downgraded. In some cases, exposure to French has fallen below 40\%. Act 212 (also introduced by Senator LaFleur) adopted by the legislature in June 2010 strives to correct this negative trend by requiring the State Board of Elementary and Secondary Education (BESE):

to develop and implement a process to certify foreign language immersion education programs as a means to provide statewide standards for foreign language immersion programs and assist and support school districts in establishing and maintaining high quality, highly effective foreign language immersion programs. (Act 212, art. 273.2, para. A)

Schools or school boards unwilling to give students the minimum time of daily instruction in the immersion language, or refusing to comply with other requirements mentioned in Act 212 shall not be labeled "Certified Foreign Language Immersion Programs" and shall most probably not receive the Louisiana Department of Education (LDE) grant ${ }^{13}$. The criteria BESE must develop will come into force at the beginning of the 2012-2013 school year. Interestingly, the legislature has not given BESE a free rein for this assignment for the main defects currently affecting immersion programs are identified and will have to be dealt with: namely the propensity of some school principals to deny their immersion classes the necessary means ("Visibility and recognition of the foreign language immersion program throughout the school"); the necessity to alleviate the phenomenon of attrition (or loss of students) which often foreshadows the permanent closure of classes ("Written policies regarding entry into and exit from the foreign language immersion program"); or the need to provide immersion teaching beyond the elementary level ("articulation, or planned articulation, throughout the elementary, secondary, and postsecondary levels of education") (Act 212, art. 273.2).

This last provision was reasserted in March 2012 with the adoption of Act 851. Immersion classes are currently mostly to be found in elementary schools and those pupils who wish to carry on with French immersion beyond 7th grade simply cannot do so in Louisiana. Act 851 aims at filling this educational gap with the creation of an exploratory committee meant to develop a plan to create an international language immersion school at the University of Louisiana at Lafayette. The establishment of such a school may still well be a long way ahead, but Act 851 nonetheless proves that both the new CODOFIL and the legislators now regard French immersion as a springboard for longer studies and the French language as a professional prospect. Philippe Gustin, a former director of CODOFIL now head of Le Centre International de Lafayette ${ }^{14}$ who 
assisted Senator LaFleur in writing out Act $679^{15}$ acknowledges the need to endow French immersion with a much larger scope:

Nous devons mettre sur pieds une articulation entre les niveaux, entre l'école primaire et le secondaire, entre le secondaire et l'université. Ce sera également un des axes principaux de la réflexion et de l'action du nouveau CODOFIL. Il faut absolument qu'on arrive à exploiter aux niveaux secondaire et supérieur les connaissances linguistiques de ces jeunes qui sortent des classes d'immersion. Comment? Peut-être en leur donnant la possibilité d'apprendre le français, mais dans un domaine extrêmement pointu. (...) Nous devons donner l'occasion à ces jeunes de se perfectionner dans un français extrêmement pointu, qui pourrait devenir, à l'université, leur objectif de carrière professionnelle. Il y a eu des développements intéressants ces dernières années, avec notamment la création de la section francophone du barreau louisianais, il pourrait y avoir la même chose avec les médecins, qui sont d'ailleurs plus nombreux que les avocats à parler français. ${ }^{16}$

Gustin's words echo what folklorist Barry Ancelet wrote more than twenty years earlier about teaching the French language in Louisiana: "the experiment to revive French remained theoretical. It had not yet made the trip home from school" (Ancelet, 351). Ancelet was then describing the FLES program, but his comment could also apply to the French immersion classes although the trip must now be extended even farther, into society as a whole. French immersion must be supported and expanded because French adds value to the cultural attractions of the state that happen to be concentrated in Acadiana. The link between tourism and culture and the economic dimension of the current French revitalization are clearly at the core of the recently adopted laws. Act 679 states it explicitly among the objectives CODOFIL is to reach:

(1) To oversee the development and expansion of the state's economic development and tourism activities designed to promote our French culture, heritage, and language. (6) To develop a certification system whereby vendors, festivals, and restaurants may be designated "Francophone Friendly" and design and issue a marquee that may be displayed by each certified entity. (Act 679, art. 651, paras. C1 C6)

The French immersion programs must therefore be regarded as a tool to increase the number of French speakers, some of whom could be employed in the tourism industry in the near future. The same idea pervades Act 106. This act seeks to establish a French Language Services Program so as to assist French-speaking visitors and Louisianians: The Louisiana French Language Services Program shall be established as provided (...) for the following purposes:

To the extent practicable, to provide state government services to French-speaking citizens and visitors in the French Language.

To assist Louisiana citizens who speak French in dealing with and receiving services from state government so as to support the long-term sustainability of Louisiana's historic French cultural heritage.

To assist French-speaking visitors to the state and thus to promote an increase in tourism and greater investment in the state from Francophone countries. (Act 106, art. 672)

It will be incumbent upon CODOFIL, under the supervision of the Department of Recreation, Culture and Tourism, to conceive and implement this program intended to supply Louisiana's public services with French-speaking employees. The audacity of this law is compensated by the prudence and caution displayed by its authors who 
refrained from setting a date for its implementation, mentioning the conditions of recruitment or establishing quotas. Yet, in spite of this lack of precision, Act 106 represents a major step towards the revitalization of the French language in Louisiana. The arguments put forward by the legislators to justify the presence of French in public services do not differ from those listed in Act 679: the economic development of Louisiana, through tourism and foreign investments, hinges on French. The authors of Act 106 bolstered this assertion with a few figures (provided by the Louisiana Chapter of the Franco-American Chamber of Commerce) and inserted in Article 671 according to which French-speaking tourists spend about $\$ 100 \mathrm{~m}$ each year in Louisiana, and the investment of French firms (mainly Veolia, EADS and Air Liquide) over the past years amounts to $\$ 1,8 \mathrm{bn}$ or 10,000 jobs (Act 106, art. 671). Had the partially French-owned aircraft maker Airbus won the $\$ 35 \mathrm{bn}$ U.S. Air Force contract to furnish a fleet of new refueling tankers, assembly plants were to open in Louisiana (as well as in Mississippi and Alabama), which is why the senators from Louisiana supported the Airbus bid in Washington.

17 The nexus between the economic benefit of the state and French immersion explains why the various French-oriented laws received a unanimous support in the Legislature $^{17}$. This political diversity alone elicits a reasonable degree of optimism about the French language in Louisiana.

\section{Assessing the French Revival}

Attempting to assess the French revival only two years after it started without the necessary hindsight may sound hasty at the very least. Still, the steep and constant decline of French in Louisiana over the past decades demands urgent actions, urgent results and therefore an urgent assessment. Not surprisingly, the success of the current French Renaissance will partly depend on the new, reformed CODOFIL or, in other words, on the people that have been appointed to its board and executive committee. Act 679 has put an end to the near absolute domination of the executive director and the ensuing inability of the committee to influence and control the strategy of the Council. Roles have been reversed as the seven members of the committee which also comprises the chairman will appoint the executive director "who shall perform such duties and possess such qualifications as established by the council" (Act 679, art. 653, para. D3a). The power of decision-making will therefore be wielded by the executive committee. Its composition offers a clear indication as to the capacity of CODOFIL to play its part. Two main trends seem to characterize the new CODOFIL: highly qualified, recognized personalities in the education sector now occupy top positions and Cajun activists, who were often kept away from the Council, are deeply involved in its running. The composition of the board reaffirms the traditional orientation of CODOFIL towards education: twelve members of the board out of twenty-one and four members of the executive committee out of seven work in the education sector and have played key-roles in immersion teaching, teachers' training or cultural studies. Nicole Boudreaux is Foreign Language Immersion Programs Lead Teacher in the Lafayette parish, Robert Lafayette founded the French Education Project at Louisiana State University (LSU) ${ }^{18}$, Tony Zaunbrecher is one of the founders of the Consortium of immersion schools ${ }^{19}$, Barry Ancelet is a renowned Cajun professor of Folklore at the University of Louisiana at Lafayette (UL), Amanda LaFleur is a Cajun linguist at LSU, 
Terri Hammatt is World Languages Program Consultant at the Department of Education. Having these experts on board should make it easier for CODOFIL to expand immersion programs throughout Acadiana.

Barely appointed, the new board of CODOFIL came up with a plan to supply immersion programs with 200 teachers in the next ten years. Named Operation Louisiana Escadrille, this plan purports to send from ten to twenty Louisiana graduate students to France each year where they will be teaching English in elementary and secondary schools while taking French classes in local universities as well as Louisiana universities through videoconference. Upon their return to Louisiana, these students will be granted a French K-12 certification and offered teaching positions in immersion classes $^{20}$.

20 According to Article 651 of Act 679, every parish in Acadiana will have to be equipped with an immersion program at the beginning of the 2015-2016 school year. In other words, CODOFIL must convince sixteen parishes (Acadia, Ascension, Avoyelles, Cameron, Evangeline, Iberville, Jefferson Davis, Lafourche, Pointe Coupee, St. Charles, St. James, St. Mary, St. John the Baptist, Terrebonne, Vermilion and West Baton Rouge) to open such a program in the next two years. If one considers the average number of French Associate Teachers in the small and middle-sized existing programs (Lafayette's and New Orleans's are out of reach for most parishes), each school board will have to hire eight teachers (7,71 to be more exact). The total number of recruited teachers will then amount to 128. Unless CODOFIL doubles its recruiting capacity, this objective will remain wishful thinking. The presence of its two honorary consuls in the executive council of CODOFIL (Christian Goudeau and Dana Kress) may convince Louisiana's main partner, France, to increase its contingent (it currently sends thirty-four teachers each year to Louisiana in accordance with the Franco-Louisianian accords for the 2008-2012 period) but the dire economic difficulties France is going through preclude any massive augmentation. The success of Operation Louisiana Escadrille appears therefore as a sine qua non for CODOFIL to supply the new programs with teachers.

21 Supply, however, may eventually turn out to be a lesser problem compared with demand. The opening of an immersion program is the responsibility of the parish school board, whose elected members' decisions are supposed to reflect the will of the constituents. The rarity of immersion classes in a majority of parishes obviously betrays the lack of interest of most voters for this type of education and may incite school boards not to readily comply with Article 651. CODOFIL is allowed to "cooperate with and advise other state agencies, including public institutions of education" but holds no power over the school boards. Convincing them to open classes could prove a most difficult if not impossible task without some kind of incentives:

J'ai visité, avec le superintendant de l'Éducation de l'État de la Louisiane, monsieur Pastorek, et beaucoup de membres de la commission de l'Éducation de l'État (BESE), et donc j'ai dit, «Écoute, nous avons déjà un très joli programme, ça s’appelle French Immersion, ça existe dans la Louisiane, tu peux le voir que ça marche très bien, et les membres ont dit 'Comment on peut améliorer le programme ?',j'ai dit, donnez une bourse, donnez quelque chose comme ça ». Donc nous avons adopté Renaissance la Louisiane. ${ }^{21}$

The Louisiana Renaissance grant (also called Language Immersion Program grant) "seeks to give language immersion programs and especially French immersion instruction in Louisiana a new momentum" (Renaissance grant, 2). The grant has 
clearly been designed to assist CODOFIL in spreading immersion instruction in Acadiana as the funding priorities are to "establish a new program in a school or a school district", and to "extend a program to other grade levels". Schools or school districts willing to expand or open a program are eligible and may submit their project. The available budget amounts to $\$ 124,000$ and up to eight awards, ranging from $\$ 5,000$ to $\$ 100,000$ may be granted to selected projects on a year-to-year basis. The recipients of the awards for the 2011-2012 and 2012-13 school years should therefore offer a clear picture of the planned expansion of immersion programs. Sadly, not a single new program has been created and two awards out of three have been allotted to schools located out of Acadiana ${ }^{22}$ simply because the school boards there did not submit any applications. The identity of the grantees evinces the reluctance of the boards to embrace French immersion and is also a reminder of how elusive a goal opening a new program in every parish in Acadiana will remain. Financial incentives alone will obviously not change the situation and the Legislature may have to interfere:

Aujourd'hui, c'est pas obligatoire d'avoir une école d'immersion. Mais, avec la bourse du BESE, (c'est le programme Renaissance La Louisiane), nous avons établi une situation où s'il y a une école qui le veut, elle peut avoir un programme d'immersion. Donc l'année prochaine, on va noter combien d'écoles ont participé, ont essayé d'avoir la bourse. Si nous trouvons qu'il y a des commissions qui font rien pour établir une école d'immersion, tu peux regarder bien que la délégation acadienne \{Acadiana Legislative Delegation\} va changer le droit une autre fois, et cette fois-là, elle va dire « T'as pas le choix, à la fin des trois ans, il faut avoir une école d'immersion. » (...) On va faire que c'est une obligation pour les commissions de l'éducation de chaque paroisse de l'avoir. ${ }^{23}$ Considering the ample power held by parish school districts, the boldness of a law that would impose on those local ministries of education the opening of an immersion program, and the probable antagonistic reactions of those fiercely independent entities, this statement made by Senator LaFleur is striking. It does confirm that the revival of French in Louisiana is not the concern or the fight of only a minority in the Legislature, but such a divisive and coercive law would seriously test the cohesion of the French immersion backers. Voters may well be tempted to share the opinions of the school boards' elected members and not that of their representatives in Baton Rouge.

Recent developments would tend to uphold such an assumption. When Governor Bobby Jindal vetoed \$ 2 million in marketing funding for the state's Department of Culture, Recreation and Tourism led by fellow Republican Jay Dardenne in June 2012, he also singled out $\$ 100,000$ meant for CODOFIL, thus depriving the agency of $2 / 5$ of its expected budget $(\$ 251,850)$ (Louisiana House Bill 1,$75 ; 293)$. The cut forced CODOFIL to downsize the 2012-2013 Escadrille Lafayette from 20 students to 7, as every student teacher costs about $\$ 7,000$. Though riled at the governor's decision, angry legislators were unable to convene an extraordinary session to overturn the vetoes mostly because they went unnoticed in Louisiana or at least did not shake off the apathy of voters with regard to CODOFIL and French immersion.

Fighting this indifference consequently appears as a prerequisite to extend immersion programs and above all to expect them to transmit a declining language. No educational system has ever been able to recreate a situation of bilingualism and save a minority language in the process if pupils are not given the opportunity to speak and hear that language outside the school premises. CODOFIL must therefore attempt to build up conditions in which speaking French is possible, interesting and profitable. 
The fertility and youth of the Louisiana music scene is a testament to the appeal Cajun French still exerts on listeners from all generations. The success this musical genre has been enjoying for more than forty years in Louisiana, and in the USA more generally cannot but strengthen positive attitudes towards Cajun French and culture. Yet, it has failed to stop or simply slow down the decrease of the number of French speakers for whom realism and pragmatism prevail over any other considerations: the inhabitants of Acadiana will not speak French because they feel the need to express their identity but because it is in their best interest to do so. After the end of the Second World War the Cajuns massively chose to become unilingual for economic reasons (Bernard). The same reasons will drive them to become bilingual again, which is why the Legislature but also the mayor of New Orleans, Mitch Landrieu ${ }^{24}$, have staked the current French renaissance on its economic fallouts. This common belief shared by some of the political leaders of the state that the enhancement of the French presence in Louisiana will generate jobs in the tourism and cultural industries certainly represents the best chance this language ever had to grow again. Yet, Governor Jindal's vetoes have also shown that this hope will remain inaccessible as long as CODOFIL does not enjoy a stronger position, which means an increased and stable budget to communicate and convince Louisianians of all ancestries that mastering French is conducive to a better professional status.

That is exactly what has been achieved in the Canadian province of Manitoba. The obvious similarities between, on the one hand, Act 106 and Manitoba's French Language Services Policy of 1999 and, on the other hand, the Louisiana Renaissance grant and the Manitoba's French School Language Revitalization Program ${ }^{25}$ leave no doubt as to from where the Louisiana legislators drew their inspiration. A quick glance at the linguistic and demographic situation of Manitoba explains their interest. Not unlike the Cajuns in Acadiana, the Franco-Manitobans are concentrated in one area of the province, around Winnipeg and they too were deprived of the right to be taught in French in 1916; according to the 2006 Canadian census, Manitoba numbered 44,110 inhabitants who spoke French at home, which makes up 3,89\% of the whole population. This percentage is almost identical with that of Louisiana where $3,85 \%$ of the total population (amounting to 4,069,923 inhabitants) may still speak French. Interestingly, the data about the respective immersion programs of the two regions appear strikingly different: whereas about 3,400 students were enrolled in immersion classes in Louisiana, it was around 18,500 in Manitoba.

The main consequence of this discrepancy can be observed in the number of English speakers capable of resorting to French, in Manitoba. According to the Manitoba Francophone Affairs Secretariat, 61,340 inhabitants belong to this category and help raise the number of French speakers up to 105,450 (MCCF), or 9,3\% of the province's population. As it is generally considered that a language may not survive with fewer than 100,000 speakers (UNESCO, 73), it is the bilingual Anglo-Manitobans trained in immersion schools who make it possible for the French language to grow in Manitoba. If demographic proportions are to be respected, Louisiana will have to increase the capacity of its immersion programs dramatically (in fact, multiply it by nineteen) and provide schooling to approximately 66,424 pupils and students ${ }^{26}$, which explains why imitating the Manitoban model makes great sense in Louisiana. Consequently, the survival and the development of French in Louisiana imply that a growing number of non-Cajun Louisianians be associated in the French revival. It also implies that even for 
an efficient CODOFIL enjoying the strong support of the Legislature, the task ahead remains formidable.

Whereas the decline of French in Louisiana seemed to be inexorable in spite of the existence of a public state agency meant to preserve and promote it, a French revival is under way. Initiated by the Louisiana Legislature, this latest renaissance is rooted in pragmatism and aims primarily at creating a visible community of French speakers, with or without the Cajuns. Modeled on the successful linguistic policy of the Canadian province of Manitoba, this movement establishes a close link between the presence of French and the economical revenues that can be drawn from it. The emphasis on the economic dimension has united politicians of all strands inciting them to reform the structures of CODOFIL and modernizing its goals while adopting the necessary laws to assist the Council. Admittedly, these efforts may come too late as most French-speaking Louisianians are no longer in their prime and Louisianians in general do not pay much heed to the travails of French. Besides, they rely on a number of uncertainties which could easily reduce to nothing the current attempt at reviving French and definitely seal its fate. The failure of Operation Louisiana Escadrille, for instance, would nip in the bud the required expansion of immersion programs that Foreign Associate Teachers alone cannot assure. So would the persisting refusal of most Acadiana school boards to set up immersion classes. However, more than two and a half centuries after the deportation of the Acadians from Canada, their Cajun descendants are still in a position to influence the course of history and give back to their original language its utilitarian value. Louisiana has often been cited as the example not to follow, especially by the activists from Quebec who even coined the term "Louisianisation" to describe the progressive loss of the French language and the lack of reaction from the community to curb it, but its newly implemented linguistic policy is setting a precedent that ought to be closely observed by all the countries wishing to restore or simply establish a richer linguistic and cultural diversity.

Bills and acts

Act 409, Louisiana Revised statutes, Chapter XIII, 1968.

Act 679 (June 2010), http://legis.state.la.us/billdata/streamdocument.asp?did=722831 (last accessed on January $\left.16^{\text {th }}, 2013\right)$.

Act 106 (June 2011), http://legis.la.gov/billdata/streamdocument.asp?did=714028 (last accessed on January $\left.16^{\text {th }}, 2013\right)$.

Act 212 (June 2011), http://legis.la.gov/billdata/streamdocument.asp?did=760362 (last accessed on January $\left.16^{\text {th }}, 2013\right)$.

Act 851 (June 2012), http://legis.la.gov/billdata/streamdocument.asp?did=812550 (last accessed on January $\left.16^{\text {th }}, 2013\right)$.

Act 202 (May 2012), http://legis.la.gov/billdata/streamdocument.asp?did=805645 (last accessed on January $\left.16^{\text {th }}, 2013\right)$.

House Bill 1, (Session 2012), http://legis.la.gov/billdata/streamdocument.asp?did=812480 (last accessed on January $16^{\text {th }}, 2013$ )

Manitoba's French Language Services Policy (1999) http://www40.statcan.gc.ca/102/cst01/ demo11c-fra.htm (last accessed on March $2^{\text {nd }}, 2011$ ).

Primary sources 
Accords franco-Louisianais (2008-2012)

http://www.consulfrance-nouvelleorleans.org/spip.php?article828 (last accessed on November $\left.21^{\text {st }}, 2011\right)$.

ALFORD, Jeremy, "Bill calls for French-immersion schools",

http://www.dailycomet.com/article/20100614/ARTICLES/100619617?p=1\&tc=pg (last accessed on January $16^{\text {th }}, 2013$ )

ANCELET, Barry, “A Perspective on Teaching the 'Problem Language' in Louisiana” in French Review 61.3, 1988, 351.

BERNARD, Shane K., The Cajuns: Americanization of a People, Jackson, University of Mississippi, 2003.

BOUDREAUX, Nicole, "Foreign Language Immersion Programs in Louisiana" in ACIE Newsletter 8.3, 2005, 5-6.

BOUDREAUX, Nicole and Stephen Caldas, "Poverty, Race, and Foreign Language Immersion: Predictors of Math and English Language Arts Performance" in Learning Languages 5.1, 1999, 12-13.

BROUSSARD, Earlene. Speech. CODOFIL's annual meeting at the Hotel Bentley in Alexandria, Louisiana. September 7th 1996 (CODOFIL Archives, Garland-Dupré Library, University of Louisiana at Lafayette).

Canadian census (2006), http://www.statcan.gc.ca/tables-tableaux/sum-som/l02/cst01/ demo11c-fra.htm (last accessed on January $16^{\text {th }}, 2013$ ).

DEGRAVE, Jérôme, "Entre Norme et identité, le CODOFIL et les programmes louisianais d'immersion en français", PhD Dissertation, University of Toulouse le Mirail, November 2011.

JAMES, E. Newell, “Intensive French Program Sparks Lafourche Debate” http:// www.dailycomet.com/article/20010813/NEWS/108130315?p=all\&tc=pgall (last accessed on January $\left.16^{\text {th }}, 2013\right)$.

HAJ-BROUSSARD, Michelle, "Language, Identity and the Achievement Gap: Comparing Experiences of African-American Students in a French Immersion and a Regular Education Context", PhD Dissertation, Louisiana State University, August 2003.

MCCF, http://www.cmfc-mccf.ca/fr/francophonie_map.php (last accessed on January $16^{\text {th }}, 2013$. Renaissance La Louisiane Grant, www.codofil.org/bilingual/ Louisiana_Renaissance_Instructions1_saveable.pdf (last accessed on June $21^{\text {st }}, 2011$ ). THIBODEAUX, John Smith, Les Francophones de Louisiane, Paris, Éditions Entente, 1977.

THOMAS, Wayne P., Collier Virginia P. and Martha Abbott, “Academic Achievement through Japanese, Spanish, or French: The First Two Years of Partial Immersion" in The Modern Language Journal 77 vol. ii, 1993, 170-9.

UNESCO, Investir dans la diversité culturelle et le dialogue interculturel, Paris, UNESCO Publishing, 2009.

\section{Secondary sources}

ALLARD, Réal and Rodrigue Landry, "French in South Louisiana: Towards Language Loss" in Journal of Multilingual and Multicultural Development vol. 17, 1996, 6-13. 
BANKSTON, Carl L. and Jacques Henry, "The Silence of the Gators: Cajun Ethnicity and Intergenerational Transmission of Louisiana French" in Journal of Multilingual and Multicultural Development vol. 19.1, 1998, 1-23.

BERNARD, Shane K., Swamp Pop: Cajun and Creole Rhythm and Blues, Jackson, University Press of Mississippi, 1996.

BROWN, Becky, "The Social Consequences of Writing Louisiana French" in Language in Society vol. 22, 1993, 67-101.

CERQUIGLINI, Bernard, "Les États-Unis d'Amérique, pays francophone" in Revue japonaise de didactique du français vol. 3. 2, 2008, 10-22.

DOMENGEAUX, James, "The United States Challenge in a Multicultural World" in Acadiana Profile vol. 1.6, 1970, 1-5.

---, "Plaidoyer pour le bilinguisme" in Louisiana Review vol. 1.2, 1972, 1-7.

DORMON, James H, The People Called Cajuns. An Introduction to an Ethnohistory, Lafayette, Louisiana, University of Southwestern Louisiana, 1983.

DUBOIS, Sylvie, "Creole and Cajun Identities: Ethnic Ties in Louisiana. The French Language and Questions of Identity", French Studies Annual Conference, Fitzwilliam College, Cambridge, United Kingdom, July 7-8 ${ }^{\text {th }}, 2004$.

DUBOIS, Sylvie, W. Margot Gautreau, Megan Mélançon and T. Veler, “The Quality of French Spoken in Louisiana: Linguistic Attitudes towards the Varieties of French in Cajun Communities" in SECOL Review vol. 19.2, 1995, 126-50.

DUBOIS, Sylvie and Megan Melançon, "Cajun is Dead - Long Live Cajun: Shifting from a Linguistic to a Cultural Community" in Journal of Sociolinguistics vol. 1.1, 1997, 63-93.

FISHMAN, Joshua A., "What Is Reversing Language Shift (RLS) and How Can It Succeed?" in Journal of Multilingual and Multicultural Development vol. 11, 1990, 5-36.

_. _. Reversing Language Shift: Theoretical and Empirical Foundations of Assistance to Threatened Languages, Clevedon, Multilingual Matters, 1991.

GELHAY, Patrick and David Marcantel, Notre langue louisianaise: Our Louisiana Language, Jennings, Louisiana, Éditions Françaises de Louisiane, 1985.

GOLD, Gerald, "The Cajun French Debate in Louisiana" in Issues in International Bilingual Education, New York, Plenum Press, 1982.

GUIDRY, Richard, “Mémoires d'un Cadien passionné" in Franco-Amérique, Dean Louder and Eric Waddell eds., Quebec, Septentrion, 2008.

HENRY, Jacques, “From ‘Acadien' to ‘Cajun' to ‘Cadien': Ethnic Labelization And Construction of Identity” in Journal of American Ethnic History vol. 17, 1998, 29-52.

HENRY, Jacques and Sara Le Ménestrel, eds., Working the Field: Accounts from French Louisiana, Westport, CT, Praeger, 2003.

LE MÉNESTREL, Sara, La Voie des Cadiens: Tourisme et identité en Louisiane, Paris, Belin, 1999.

MARCANTEL, David, "Faut que ça change" in LA Gazette de Louisiane vol. 1.1, 1992, 7-10.

MURPHY, Alexander, "Placing Louisiana in the Francophone World: Opportunities and Challenges" in Atlantic Studies vol. 5.3, December 2008, 363-81. 
NATSIS, James J., "Legislation and Language: The Politics of Speaking French in Louisiana" in The French Review vol. 73.2, 1999, 325-31.

PAQUETTE, André, “1978 Evaluation of Louisiana State-Wide CODOFIL French Programs”, Unpublished report, Archives CODOFIL, Garland-Dupré Library, University of Louisiana at Lafayette.

PICONE, Michael D., "Enclave Dialect Contraction: an External Overview of Louisiana French" in American Speech vol. 72.2, 1997, 117-53.

\section{NOTES}

1. The Cajuns are the descendants of Acadian exiles deported from French Acadia in 1754 by the British.

2. According to Legislative Act 409, CODOFIL is empowered to « do any and all things necessary to accomplish the development, utilization, and preservation of the French language as found in Louisiana for the cultural, economic and touristic benefit of the state. »

3. The 28th district covers the parishes of Evangeline, Allen, and Avoyelles, along with parts of St. Landry and Acadia. Senator LaFleur serves as a member of several senate committees (Judiciary $\mathrm{B}$, Insurance) and is currently Vice-Chairman of the Education Committee. He is also a member of the joint Legislative Committee on Budget.

4. The real starting point of this so-called French renaissance may have been the adoption of Act 760 in June 2008 as it removed CODOFIL from the Department of Education and placed it within the Department of Culture, Recreation and Tourism. Largely unnoticed at the time, it was the first law dealing with French in 33 years since the vote of Act 714 in 1975.

5. Speech delivered by Earlene Broussard during the annual meeting of CODOFIL at the Bentley Hotel of Alexandria, Louisiana, on Septemer 7th, 1996 (CODOFIL archives, Louisiana Room, Garland-Dupré Library)

6. In 1991, $63 \%$ of public schools had an FLES program. They were down to $29 \%$ in 2006 . (Louisiana Department of Education)

7. Source : Louisiana Department of Education.

8. Source : Louisiana Department of Education.

9. According to the 2000 US census, Lafourche parish comprised 19,12\% Cajun speakers whereas Lafayette, the self-proclaimed heart of Acadiana, only reached $14,47 \%$.

10. Senator Eric LaFleur. Personal interview. February 24th, 2011.

11. LaFleur was elected to the Louisiana Senate in 2008. In 2010, he was appointed vice-chairman of the Senate Education Committee. He is the main author of Act 679.

12. Two examples bear out CODOFIL's discretion: the agency did not celebrate its fortieth aniversary in 2008 ; when conducting fieldwork for a sociological survey on the Cajuns in 1997, Professor Dubois from Louisiana State University in Baton Rouge was often answered «CODOwhat? » whenever she mentioned CODOFIL to the respondents (Professor Sylvie Dubois. Personal interview. February 10th, 2009).

13. French immersion programs rely heavily on foreign teachers (French Associate Teachers or FATs) recruited by CODOFIL. As an incentive for schools to open such programs, the LDE gives school boards a yearly grant amounting to about $\$ 20,000$ for each recruited FAT. 
14. Le Centre International's main activity consists in attracting businesses and tourists to the Lafayette area.

15. Philippe Gustin is also a member of the new CODOFIL board. He was appointed by the Louisiana Section of the Association des Parlementaires Francophones.

16. Philippe Gustin. Personal interview. February 22nd, 2011.

17. The 40 authors of Act 679 comprised 22 Democrats, 17 Republicans and 1 independent. 22 of them were members of the Acadian Legislative Delegation (Cajun caucus).

18. Created in 1987, the French Education Project's mission initially consisted in providing Louisiana schools with locally-trained French teachers.

19. The Consortium of Immersion Schools was created in 1993 so as to coordinate the various immersion programs of Louisiana.

20. 10 students participated in the program in 2011-2012. The current 2012-2013 Escadrille numbers 7 students.

21. Senator Eric LaFleur. Personal interview. February 24th, 2011.

22. The recipients for 2011-2012 and 2012-2013 are the same, namely the Calcasieu school district, the new Lycée Français de la Nouvelle Orléans and the Audubon Charter School in New Orleans (Source : Louisiana Department of Education)

23. Eric LaFleur. Personal interview. February 24th, 2011.

24. During his tenure as lieutenant-governor (2004-2010), Landrieu created, on the model of the economic forum of Davos, the World Cultural Economic Forum which aims at increasing the profits of the cultural sector.

25. The brochure describing the Louisiana Renaissance grant explicitly acknowledges the link with the Manitoban program. Moreover, special thanks are addressed to the Premier of Manitoba, to some members of the Legislative Assembly and to the executive director of the province's Francophone Affairs Secretariat.

26. The 18,500 pupils enrolled in Manitoba' immersion classes represent $1,63 \%$ of the population. Applied to the population of Louisiana $(4,069,923)$, this percentage corresponds to 66,424 pupils.

\section{AUTEUR}

\section{JÉRÔME DEGRAVE}

Lycée Jean Mermoz, Dakar 